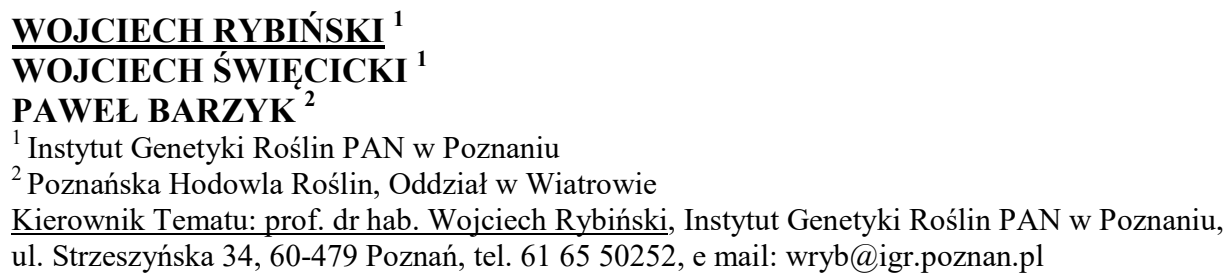

Prace zostały wykonane $w$ ramach badań podstawowych na rzecz postęp biologicznego $w$ produkcji roślinnej na podstawie decyzji Ministra Rolnictwa i Rozwoju Wsi nr HOR.hn.802.18.2018, Zadanie 42.

\title{
Analiza zmienności genetycznej i piramidyzacja genów warunkujących cechy użytkowe łubinu białego
}

\section{Estimation of genetic variability and pyramiding of genes controlling agricultural traits of white lupin}

\author{
Słowa kluczowe: alkaloidy, antraknoza, łubin biały, krzyżowania zbliżające, mutageneza, tłuszcz, \\ wczesność
}

\section{CEL TEMATU I BADAŃ}

Łubin biały ma jeden $\mathrm{z}$ najstarszych rodowodów spośród gatunków uprawianych w Europie. Jego uprawa w Egipcie datuje się na rok 330 p.n.e., skąd poprzez Grecję dotarł do Włoch. Z uwagi na mniej korzystne warunki klimatyczne w Centralnej Europie gatunku tego nie uprawiano, a dopiero udane doświadczenia Wulfena w Niemczech w roku 1810 zwróciły uwagę na wartość roślin łubinu białego w użyźnianiu gleby. Dotąd łubin biały np. w Polsce $\mathrm{i}$ w Niemczech nie stał się tak rozpowszechniony (głównie z powodu braku odpowiednich odmian) jak łubin żółty, a zwłaszcza wąskolistny. Jest gatunkiem mało poznanym od strony genetycznej. Aby zwiększyć jego powierzchnię uprawy i wykorzystanie należy ulepszyć w odmianach uprawnych kilka cech: wczesność i odporność na antraknozę oraz obniżyć zawartość alkaloidów i podwyższyć zawartość tłuszczu. Celem proponowanych badań w aspekcie wieloletnim jest zidentyfikowanie i selekcja pożądanych cech łubinu białego w światowych zbiorach kolekcyjnych lub wśród mutacji indukowanych, określenie sposobu dziedziczenia oraz łączna introdukcja cech do genotypów o wysokiej wartości użytkowej. Równoległe opracowanie populacji mapującej, której typ określa się w literaturze jako „magic population” stanowić będzie 
punkt wyjścia do pogłębionych badań genetyczno-molekularnych. Realizacja powyższego jest niezbędnym warunkiem, aby łubin biały stał się cenionym gatunkiem uprawnym, konkurencyjnym dla głównych roślin strączkowych, źródłem wysokoenergetycznej paszy białkowej dla drobiu i trzody chlewnej.

\section{WYNIKI}

W ramach zdania 42 badania realizowano $w$ trzech następujących tematach badawczych:

1. Temat badawczy 1: Indukowanie mutacji. Selekcja w mutagenezie łubinu białego jest ukierunkowana na identyfikacje zmutowanych form o wczesnym dojrzewaniu i korzystnym hodowlanie fenotypie obserwowanym w polu. W roku 2014 traktowano chemomutagenem (MNU) nasion krajowej odmiany uprawnej Butan trzema wybranymi dawkami mutagenu dla uzyskania populacji mutacyjnych $\mathrm{w}$ kolejnych latach i pokoleniach. Prace w bieżącym roku obejmowały pokolenie $\mathrm{M}_{5}$.

2. Temat badawczy 2: Krzyżowania zbliżające. Uwzględniają one dwie cechy (zawartość tłuszczu i wczesność dojrzewania) i zróżnicowane podłoże genetyczne (odmiany uprawne). Druga para cech w krzyżowaniach zbliżających uwzględnia zawartość alkaloidów i odporność na antraknozę i zróżnicowane podłoże genetyczne (odmiany uprawne). W bieżącym roku rozpoczęto prace nad oceną sposobu dziedziczenia alkaloidów jak również nad łączną inkorporacją cechy wczesności i wysokiej zawartości tłuszczu do jednego genotypu na drodze krzyżowania zbliżającego.

3. Temat badawczy 3: Wyprowadzanie populacji mapującej. W roku ubiegłym z krzyżówki formy dzikiej z odmianą uprawną (AL. $22 \times$ Boros) uzyskano nasiona roślin $\mathrm{F}_{2}$, a w roku bieżącym rośliny pokolenia $\mathrm{F}_{3}$.

\section{TEMAT 1}

W bieżącym roku (pokolenie $\mathrm{M}_{5}$ ) oceniano stopień wczesności 123 form wczesnych lub dojrzewających na poziomie odmiany Butan wybranych w ubiegłorocznym pokoleniu $\mathrm{M}_{4}$. Materiał obejmujący 68 form z dawki mutagenu $0,8 \mathrm{mM}$ i $55 \mathrm{z}$ dawki $1,2 \mathrm{~mm}$ potwierdził obecność form wczesnych $\mathrm{w}$ tegorocznym pokoleniu $\mathrm{M}_{5}$ i trafność ich selekcji w roku ubiegłym. Na podstawie obserwacji polowych z ocenianego materiału pochodzącego $\mathrm{z}$ obydwu dawek mutagenu ujawniono 18 najwcześniejszych form $\mathrm{w}$ porównaniu $\mathrm{z}$ odmianą kontrolną Butan. Część obiektów (24 formy mutacyjne) dojrzewało jeden lub dwa dni później. Pozostałe formy zaliczono do grupy wczesnych, dojrzewających na poziomie odmiany Butan, uznawanej w krajowych wykazie odmian łubinu białego za wcześnie dojrzewającą. Pod względem cech struktury plonu generalnie formy mutacyjne ustępowały wysokoplennej odmianie Butan, aczkolwiek zidentyfikowano nieliczne formy mutacyjne plenniejsze lub plonujące co najmniej na jej poziomie. O właściwym doborze dawek mutagenu może świadczyć ich efektywność w kierunku pojawiania się między innymi roślin o zmianach morfologicznych, roślin 
chlorotycznych i o zmienionej barwie kwiatów. Na szczególne wyróżnienie zasługuje zidentyfikowanie jednej formy o znacznej tolerancji na fusarium, jak i dwóch form epigonalnych, przy tradycyjnym charakterze wzrostu jaki reprezentuje odmiana wyjściowej Butan.

\section{TEMAT 2}

W odniesieniu do pierwszej pary cech (trzy kombinacje: forma o zwiększonej tolerancji na antraknozę $\times$ odmiana i formy niskoalkaloidowe $\times$ odmiana) w roku bieżącym analizowano rośliny pokolenia $\mathrm{F}_{4}$

Analizy na zawartość alkaloidów $\mathrm{w}$ potomstwie mieszańcowym pokolenia $\mathrm{F}_{4}$ pochodzącym z trzech kombinacji krzyżówkowych pozwoliły ujawnić szeroki zakres zmienności tej cechy jak i w dalszej kolejności dokonać wyboru mieszańców o bardzo niskiej zawartości alkaloidów w porównaniu z wzorcem, którą była odmiana uprawna Butan. Wykazano, że najkorzystniejszą kombinacją krzyżówkową była krzyżówka B17 (niskoalkaloidowa odmiana Amiga $\times$ odmiana uprawna Pikador) w której ujawniono najwięcej niskoalkaloidowych mieszańców w zakresie zmienności od 0,0004\% do $0,0395 \%$, przy średniej zawartości alkaloidów na poziomie $0,0242 \% \mathrm{w}$ nasionach wzorca, odmiany Butan. Dla 11 form o najniższej zawartości alkaloidów zakres zmienności tej cechy zamykał się w przedziale od $0,0004 \%$ do $0,0008 \%$. Dla określenia sposobu dziedziczenia alkaloidów wykonano krzyżowania dialleliczne w 10 kombinacjach krzyżówkowych, z wykorzystaniem pięciu linii o możliwie szerokim zakresie zróżnicowania zawartości alkaloidów. Pośród ocenianych obiektów kolekcyjnych po infekcji roślin w szklarni przez grzyb Colletotrichum lupini, nie zidentyfikowano form o pełnej odporności na antraknozę. Stwierdzono natomiast szeroki zakres reakcji roślin na infekcję wyrażony zróżnicowanym stopniem porażenia w odniesieniu do poszczególnych obiektów kolekcyjnych. Formy o najmniejszym stopniu podatności (zwiększonej tolerancji) na antraknozę w zakresie 1-2 i 2-3 w 9- stopniowej skali (9 - całkowite porażenie) mogą zostać wykorzystane w dalszych etapach prac zadania badawczego.

$\mathrm{W}$ odniesieniu do drugiej pary cech, zastosowane kombinacje krzyżowań obiektów kolekcyjnych o podwyższonej zawartości tłuszczu i wcześniejszym dojrzewaniu $\mathrm{z}$ wybranymi odmianami uprawnymi pozwoliły na uzyskanie mieszańców pokolenia $\mathrm{F}_{5}$ o poszerzonym zakresie zmienności ocenianych cech $\mathrm{w}$ stosunku do ich form rodzicielskich. Pod względem efektywności uzyskiwania najwcześniejszych mieszańców podobnie jak w roku ubiegłym (pokolenie $\mathrm{F}_{4}$ ) najlepszą okazała się kombinacja B1 (Damascus $\times$ Boros), $z$ której wyselekcjonowano mieszańce $F_{5}$ o najwcześniejszym dojrzewaniu w porównaniu z mieszańcami z pozostałych pięciu kombinacji i rodzin. Nie mniej wartościowymi okazały się także dwie dalsze kombinacje: B2 (Damascus $x$ Pikador) i B6 (MJS208-1 × Wat). Wskazuje to na znaczenie odpowiedniego doboru komponentów rodzicielskich do krzyżowań i wysoką zdolność kombinacyjną wspomnianych krzyżówek $\mathrm{z}$ ukierunkowaniem segregacji $\mathrm{w}$ kierunku pojawiania się form o najwcześniejszym dojrzewaniu. 
$\mathrm{Na}$ podstawie wcześniej wykonanych analiz chemicznych, potwierdzono trafność wyboru do badań w roku $2017\left(\mathrm{~F}_{4}\right)$ kombinacji krzyżówkowej AL. $22 \times$ Kalina. Pozwoliło to uzyskać w potomstwie mieszańcowym szeroki zakres zmienności cechy zawartości tłuszczu i składu kwasów tłuszczowych, a w efekcie finalnym zidentyfikować mieszańce wysokotłuszczowe o korzystnym z żywieniowego punktu widzenia profilu kwasów tłuszczowych. Wysoka wartość kombinacyjną tej krzyżówki potwierdzono w tegorocznym pokoleniu $\mathrm{F}_{5}$. Nasiona mieszańców w tym pokoleniu okazały się bogatym źródłem zmienności zawartości thuszczu w szerokim zakresie od 12,1\% do 15,6\%. Umożliwiło to wybrać obiekty wysokotłuszczowe o zawartości powyżej $14 \%$, a także $15 \% \mathrm{w}$ nasionach trzech mieszańców. W odniesieniu do danych literaturowych, nasiona wysokotłuszczowych form łubinu białego przewyższają pod tym względem nasiona zarówno łubinu żółtego jak i wąskolistnego. Na podstawie ocenianych mieszańców potwierdzono wystąpienie korzystnego stosunku kwasów omega-3 do omega-6, (obserwowano to także we wszystkich wcześniejszych pokoleniach), to jest kwasu linolenowego do linolowego na poziomie 1:2. Według danych literaturowych stosunek obydwu nienasyconych kwasów uważany jest za prawie idealny $\mathrm{z}$ diecie ludzi jak żywieniu zwierząt. Dla łącznej inkorporacji cechy wczesności i wysokiej zawartości tłuszczu w jeden genotyp wykonano krzyżowania obejmujące najwartościowsze mieszańce pod względem obydwu cech. $\mathrm{W}$ roku bieżącym uzyskano rośliny pokolenia $\mathrm{F}_{2}$.

\section{TEMAT 3}

Prace nad położeniem genów i oceną grup sprzężeń pozwalają na utworzenie mapy genetycznej Bardzo ważnym etapem jest tu opracowanie i wytworzenie adekwatnych populacji mapujących. Populacje te winny odznaczać się dużym zróżnicowaniem między liniami, ale ponadto linie winny być jednolite, czyli wysoce homozygotyczne. W ramach prowadzonego tematu rozpoczęliśmy prace nad uzyskaniem krajowej populacji mapującej $\mathrm{w}$ łubinie białym. Dla uwzględnienia możliwie szerokiego polimorfizmu wybór form rodzicielskich oparto na dużej liczbie przeciwstawnych alleli genów warunkujących badane cechy użytkowe (linia dzika $\times$ odmiana uprawna). Warunki te spełnia linia AL 22 charakteryzująca się tradycyjnym typem wzrostu, wysoką zawartością alkaloidów i thuszczu oraz odmiana uprawna Boros o samokończącym typie wzrostu oraz niskiej zawartości alkaloidów i tłuszczu. Z wysianych nasion rozmnażanych na polu doświadczalnym $\mathrm{w}$ Wiatrowie $\mathrm{w}$ roku ubiegłym zebrano rośliny pokolenia $\mathrm{F}_{2}$ których nasiona umożliwiły w bieżącym roku uzyskanie roślin pokolenia $\mathrm{F}_{3}$. Uzyskane nasiona pozwolą na kontynuacje wyprowadzania populacji mapującej poprzez rozmnożenia w kolejnych latach. 